\title{
Ampulla of Vater Cancer pN2 TNM Finding V8
}

National Cancer Institute

\section{Source}

National Cancer Institute. Ampulla of Vater Cancer pN2 TNM Finding v8. NCI Thesaurus.

Code C134861.

Ampulla of Vater cancer with metastasis to four or more regional lymph nodes. (from AJCC 8th Ed.) 